Science, Technology and Development 35 (2): 75-81, 2016

ISSN 0254-6418 / DOI: 10.3923/std.2016.75.81

(C) 2016 Pakistan Council for Science and Technology

\title{
Effect of Foliar Application of Micro-nutrient and Soil Condition on Growth and Yield of Sweet Pepper (Capsicum annuum L.)
}

\author{
${ }^{1}$ Muhammad Azam, ${ }^{2}$ Muhammad Noman, ${ }^{1}$ Nadeem Akhtar Abbasi, ${ }^{2}$ Aasia Ramzan, \\ ${ }^{2}$ Muhammad Imran, ${ }^{2}$ Asim Hayat, ${ }^{2}$ Huma Abbas and ${ }^{2}$ Atif Akram \\ ${ }^{1}$ PMAS-Arid Agriculture University, Rawalpindi, Pakistan \\ ${ }^{2}$ National Agricultural Research Centre, Islamabad, Pakistan
}

\begin{abstract}
Sweet pepper (Capsicum annuum L.) is a main crop of Solanaceae family. Pepper (Capsicum annuum) is most susceptible to drought among horticultural crops. From many studies it is clear that limited water supply, during pepper growth, has negative effect on yield. Adequate irrigation during entire growth period is necessary for good yields. With scarce availability of water, the farmer must find a combination of management practices and varietals approach to overcome this problem. The present study was conducted to evaluate a suitable foliar application of calcium and potassium to alleviate drought stress in bell pepper. The research was carried out in the experimental area, PMAS-Arid Agriculture University, Rawalpindi, during the year 2012. A pot experiment was conducted in the green house to study the effect of foliar applied different concentrations (5, 10 and $15 \mathrm{mM}$ ) of calcium chloride and potassium chloride to alleviate drought stress in bell pepper plants. Both experiments were conducted according to CRD (completely randomized design). Calcium and potassium significantly improved all parameters, i.e., photosynthesis rate, transpiration rate, leaf free proline, leaf osmotic potential, fruits weight, etc. Calcium chloride at $10 \mathrm{mM}$ showed better results than other treatments under normal irrigation while calcium chloride at $15 \mathrm{mM}$ showed better results under drought conditions. So, it may be concluded from present study that drought tolerance in bell pepper could be improved by foliar application of calcium and potassium chlorides.
\end{abstract}

Key words: Bell pepper, drought, foliar, $\mathrm{KNO}^{3}$, yield

\section{INTRODUCTION}

Sweet pepper (Capsicum annuum L.) is a main crop of Solanaceae family. Commercially Vietnam is the leading producer with $1,63,000.00 \mathrm{t}$ following Indonesia $(88,700.00 \mathrm{t})$, India $(53,000.00 \mathrm{t})$ and China with 42,312.00 t (FAO., 2013). Sub-urban areas are major producers in Pakistan. California wonder, Yolo wonder, Capistrano, etc. are the cultivars available in Pakistan.

Drought is the most severe problem in crop production in arid and semi-arid regions of the world (Debaeke and Aboudrare, 2004). With scarce availability of water, the farmer must find a combination of management practices and varietals approach to overcome this problem. Pepper (Capsicum annuum L.) is most susceptible to drought among horticultural crops (Gonzalez-Dugo et al., 2007). From many studies, it is clear that limited water supply, during pepper growth, has negative effects on yield. Drought reduced number of fruits, due to reduced plant size and limited availability of assimilates during fruit development and maturation stage (Hsiao, 1993). Drought reduced the photosynthetic rate, stomatal conductance and internal $\mathrm{CO}_{2}$ concentration.
Drought also decreased the number of leaves, branches and leaf area (Ferrara et al., 2011).

Different nutrients can play an important role to cope with drought in plants. Calcium is considered as a second messenger, which plays a significant part in signal transduction (Bush, 1995). It also has an effective role in growth, development of plants and in regulating the physiological and biochemical metabolism of cells and tissues (Sanders and Harper, 1999). Moreover, a transitory opening of $\mathrm{Ca}^{2+}$ channel in the plasma membrane or endo-membranes takes place under drought, which allows $\mathrm{Ca}^{2+}$ to change many cellular activities, such as, ionic balance associated with stomatal closing (Ward and Schroeder, 1994), CHO metabolism (Brauer et al., 1990). Calcium regulates leaf turgor pressure and cell size (Gilroy et al., 1990; Cosgrove and Hedrich, 1991). $\mathrm{Ca}^{2+}$ also modulate gene expression (Braam, 1992), mitosis (Lino et al., 1989), excretion and activation of many enzymes related with photosystem II, ATPase and chloroplast development (Bush, 1995; Tester and Zorec, 1992). It also has an active role in anti-oxidants activities (Zhang et al., 2001). $\mathrm{Ca}^{2+}$ is not the single factor, which controls these activities but 
in the transduction pathway calcium is involved to stimulate complex cellular response.

In the physiology of plant water relations and crops production potassium $\left(\mathrm{K}^{+}\right)$is another important macronutrient and an essential ion. It is involved in stomatal closure, osmoregulation, enzyme activation; regulation of cell volume, non-diffusible negatively charged ions are neutralized by potassium and polarization of membrane. To maintain normal growth and development, a considerable amount of $\mathrm{K}^{+}$is required by plants (Eisenman, 1961; Epstein, 1972; Clarkson and Hanson, 1980; Flowers and Lauchli, 1983; Kochian and Lucas, 1988; Schroeder et al., 1994; Maathuis and Sanders, 1996; Elumalai et al., 2002). Plants with $\mathrm{K}^{+}$deficiencies are more vulnerable to drought than the plants which have sufficient $\mathrm{K}^{+}$. These plants have better hydrated tissues than those having inadequate supply of $\mathrm{K}^{+}$(Mengel and Kirkby, 2001). Potassium accumulates in root xylem vessels and stomata cells and helps in water uptake by roots (Lauchli, 1984) and regulates stomatal closure and transpiration (Hsiao and Lauchli, 1986). Various studies have shown that potassium starvation in plants inhibits stomata closure and promotes transpiration (Bednarz et al., 1998; Cabanero and Carvajal, 2007).

Foliar fertilization is mostly a used-practice to correct nutritional deficiencies in plants caused by improper supply of nutrients to roots (Ling and Silberbush, 2002). Maynard and Hochmuth (1997) stated that immobile nutrients, like calcium and boron, should be applied in small amounts at high frequency rather than in one application to correct temporary deficiencies in vegetables. Exogenous fertilizers are absorbed by leaves, the site where they are used as quite fast acting, while plants may never get used much of the fertilizers applied to soil. Exogenously applied nutrients also help to overcome the soil inability to transfer nutrients to the plant under water deficit conditions. Foliar application of potassium in tomato increased fruit yield and net income. In pepper foliar application of potassium increased fruit yield, numbers of fruits per plant and yield of dry fruit (Palaniappan et al., 1999).

Keeping in view, the role of calcium and potassium in plants, the present study was conducted to evaluate a suitable foliar application of calcium and potassium to alleviate drought stress in bell pepper.

\section{MATERIALS AND METHODS}

This study was carried out in the field area of Pir Mehr Ali Shah Arid Agriculture University, Rawalpindi during the year 2012. Experiment was conducted according to CRD (completely randomized design). Fisher analysis of variance techniques were used to analyze the recorded data. LSD test at 5 percent probability level was used to compare significant differences among the treatments means (Steel et al., 1997).

Seeds of bell pepper c.v. "California wonder" were sown in March, 2012 and irrigated daily till germination was completed. These seedlings were transplanted (after five weeks) into clay pots (14") containing $10 \mathrm{~kg}$ mixture of soil, sand and farm yard manure in the proportion of 2:1:1, respectively. There were three replications in each treatment. Foliar application was done one time throughout the experiment. The experiment comprised of following treatments:

Factor A = Field capacity levels:

$\mathrm{F}_{0}=$ Control (100\% of field capacity)

$\mathrm{F}_{1}=50 \%$ of field capacity

Factor B = Chemical levels:

$\mathrm{T}_{0}=$ Control

$\mathrm{T}_{1}=5 \mathrm{mMCaCl}_{2}$

$\mathrm{T}_{2}=10 \mathrm{mM} \mathrm{CaCl}_{2}$

$\mathrm{T}_{3}=15 \mathrm{mM} \mathrm{CaCl}_{2}$

$\mathrm{T}_{4}=5 \mathrm{mM} \mathrm{KCl}$

$\mathrm{T}_{5}=10 \mathrm{mM} \mathrm{KCl}$

$\mathrm{T}_{6}=15 \mathrm{mM} \mathrm{Kcl}$

Treatment application: In the present study, two weeks after transplanting field capacity was maintained 100 and $50 \%$ throughout the experiment. Three weeks after transplanting foliar application of $\mathrm{CaCl}_{2}$ and $\mathrm{KCl}$ was done for one time. The field capacity was maintained at desired level by weighing the pots daily and adding the amount of water which is depleted. After one week of foliar application data regarding photosynthesis rate and transpiration rate was measured, using portable Infra-Red Gas Analyzer (IRGA). After one week of foliar application leaf free proline was estimated, following the observations of Bates et al. (1973) and leaf osmotic potential was determined by storing the leaves below $-20^{\circ} \mathrm{C}$ for seven days, extract the sap and noted the reading using osmometer. Number of flowers and fruits weight was recorded during crop growth. Root length, shoot dry weight and root dry weight were recorded after harvest.

\section{RESULTS AND DISCUSSION}

Rate of photosynthesis a $\left(\mu \mathrm{mol} \mathrm{CO}_{2} \mathrm{~m}^{-2} \mathrm{sec}^{-1}\right)$ : Table 1 shows the effect of different concentrations of $\mathrm{CaCl}_{2}$ and $\mathrm{KCl}$ on photosynthetic rate of bell pepper. At $100 \%$ of field capacity maximum photosynthetic rate was 
Sci. Technol. Dev., 35 (2): 75-81, 2016

Table 1: Photosynthesis rate, transpiration rate, proline contents and osmotic potential at 100 and $50 \%$ of field capacity under different treatments of calcium chloride and potassium chloride

\begin{tabular}{|c|c|c|c|c|c|c|c|c|}
\hline \multirow[b]{2}{*}{ Treatments } & \multicolumn{2}{|c|}{$\begin{array}{l}\text { Photosynthesis rate } \\
\left(\mu \mathrm{mol} \mathrm{CO}_{2} \mathrm{~m}^{-2} \mathrm{sec}^{-1}\right)\end{array}$} & \multicolumn{2}{|c|}{ 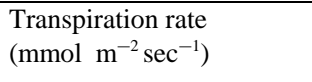 } & \multicolumn{2}{|c|}{ Proline contents $\left(\mathrm{mg} \mathrm{g}^{-1}\right.$ ) } & \multicolumn{2}{|c|}{ Osmotic potential (-bars) } \\
\hline & $\mathrm{F}_{0}$ & $\mathrm{~F}_{1}$ & $\mathrm{~F}_{0}$ & $\mathrm{~F}_{1}$ & $\mathrm{~F}_{0}$ & $\mathrm{~F}_{1}$ & $\mathrm{~F}_{0}$ & $\mathrm{~F}_{1}$ \\
\hline $\mathrm{T}_{0}$ & $15.48^{\text {defg }}$ & $5.42^{\mathrm{H}}$ & $5.13^{\mathrm{b}}$ & $6.08^{\mathrm{a}}$ & $0.31^{\mathrm{g}}$ & $1.31^{\mathrm{efg}}$ & $13.96^{\mathrm{h}}$ & $16.62^{\text {cde }}$ \\
\hline $\mathrm{T}_{1}$ & $17.34^{\text {cdef }}$ & $10.83^{G}$ & $4.46^{\text {cde }}$ & $3.96^{\mathrm{efg}}$ & $1.32^{\mathrm{efg}}$ & $1.64^{\mathrm{def}}$ & $15.35^{\mathrm{fg}}$ & $17.70^{\mathrm{bc}}$ \\
\hline $\mathrm{T}_{2}$ & $19.37^{\mathrm{bcd}}$ & $11.53^{\mathrm{G}}$ & $3.58^{\mathrm{g}}$ & $4.07^{\text {defg }}$ & $1.87^{\text {cdef }}$ & $2.92^{\mathrm{Bc}}$ & $16.39^{\mathrm{def}}$ & $17.31^{\mathrm{bcc}}$ \\
\hline $\mathrm{T}_{3}$ & $22.34^{\mathrm{abc}}$ & $11.94^{\mathrm{G}}$ & $4.36^{\text {cde }}$ & $3.59^{g}$ & $0.93^{\mathrm{fg}}$ & $4.29^{\mathrm{A}}$ & $15.98^{\mathrm{ef}}$ & $19.87^{\mathrm{a}}$ \\
\hline $\mathrm{T}_{4}$ & $17.95^{\text {cde }}$ & $12.32^{\mathrm{Fg}}$ & $4.65^{\mathrm{bc}}$ & $3.78^{\mathrm{fg}}$ & $0.46^{\mathrm{g}}$ & $2.49^{\mathrm{cd}}$ & $14.67^{\mathrm{gf}}$ & $17.64^{\mathrm{bc}}$ \\
\hline $\mathrm{T}_{5}$ & $24.24^{\mathrm{ab}}$ & $12.31^{\mathrm{fg}}$ & $4.52^{\mathrm{cd}}$ & $3.95^{\mathrm{efg}}$ & $1.09^{\mathrm{efg}}$ & $2.02^{\text {cde }}$ & $15.54^{\mathrm{efg}}$ & $19.37^{\mathrm{a}}$ \\
\hline $\mathrm{T}_{6}$ & $25.21^{\mathrm{a}}$ & $13.33^{\mathrm{Efg}}$ & $4.14^{\text {cdef }}$ & $4.67^{\mathrm{bc}}$ & $1.33^{\mathrm{efg}}$ & $3.69^{\mathrm{ab}}$ & $16.22^{\text {def }}$ & $17.86^{\mathrm{b}}$ \\
\hline
\end{tabular}

given by $15 \mathrm{mM} \mathrm{KCl} \mathrm{(25.21)} \mathrm{while} \mathrm{it} \mathrm{was} \mathrm{minimum} \mathrm{in}$ control (15.48). Water deficit significantly reduced the photosynthetic rate. At $50 \%$ of field capacity maximum photosynthetic rate (13.33) was observed in $\mathrm{KCl}$ at $15 \mathrm{mM}$ concentration while it was minimum (5.4) in control. Photosynthetic rate was increased with the increase in concentrations of $\mathrm{CaCl}_{2}$ and $\mathrm{KCl}$.

Increase in photosynthetic rate might be due to role of potassium and calcium in different enzymatic activities and regulation of stomatal activities. Foliar application of calcium nitrate on rice plants increased photosynthetic rate by 22 percent as compared to control plants (Sultana et al., 2001). Potassium ions affect water movement in whole plant; maintain cell pressure and the opening and closing of stomata is regulated by potassium (Martens and Arny, 1967; Yin and Vyn, 2002). Our result also agreed with Pothalkar (2007), who described that photosynthetic rate was increased with application of potassium chloride.

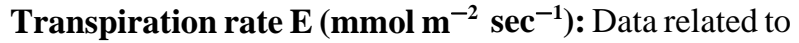
transpiration rate is shown in Table 1 , which revealed that at $100 \%$ of field capacity transpiration rate was maximum for control, i.e., 5.13, while it was minimum for $15 \mathrm{mM}$ $\mathrm{KCl}$, i.e., 4.14. Transpiration rate reduced with increase in concentration of $\mathrm{KCl}$ but as we increased concentration of $\mathrm{CaCl}_{2}$ from $10-15 \mathrm{mM}$, the transpiration rate was increased, while transpiration rate was increased under drought. There was maximum transpiration rate, i.e., $6.08 \mathrm{mmolm}^{-2} \mathrm{sec}^{-1}$ in control while $\mathrm{CaCl}_{2}$ at $15 \mathrm{mM}$ showed minimum transpiration rate, i.e., $3.59 \mathrm{mmol} \mathrm{m}^{-2} \mathrm{sec}^{-1}$. Transpiration rate showed a declining trend with increase of $\mathrm{CaCl}_{2}$ concentrations from 3.96-3.59. Potassium chloride plays role in regulation of stomatal activity. Reduction in transpiration rate may be result of this function. Transpiration rate of maize was less when $\mathrm{K}$ was applied (Siddique et al., 2000; Hirayama et al., 2006).

Osmotic potential (-bars): Different treatments of $\mathrm{CaCl}_{2}$ and $\mathrm{KCl}$ showed a significant effect on osmotic potential of bell pepper (Table 1). Maximum osmotic potential (16.39) was recorded in $10 \mathrm{mM} \mathrm{CaCl}_{2}$ followed by $15 \mathrm{mM} \mathrm{KCl}$, i.e., 16.22 bars. Osmotic potential showed an increasing trend with the increase in concentration of $\mathrm{KCl}$ from 14.67 bars to 16.22 bars for $5-15 \mathrm{mM}$ concentration, respectively. At $50 \%$ of field capacity maximum osmotic potential (19.87) was recorded in $15 \mathrm{mM} \mathrm{CaCl}_{2}$ followed by $10 \mathrm{mM} \mathrm{KCl}$, i.e., -19.37 bars. Osmotic potential showed an increasing trend with the increase in concentration of $\mathrm{CaCl}_{2}$ from 17.70 bars to 19.87 bars for 5-15 mM concentration, respectively.

Taiz and Zeiger (2002) stated that osmo-regulation is an essential process for normal cellular metabolism. Osmotic potential and turgor pressure of the cells are maintained by K Hsiao (1973) and Lindhauer (1987). Calcium regulates turgor pressure by regulating osmotic potential (Cosgrove and Hedrich, 1991).

Potassium helps in osmo-regulation of plant cell, assists in opening and closing of stomata (Mengel and Kirkby, 1987). Calcium role as calmodulin adjusts osmotic potential and increases plant growth under water deficit. Foliar application of calcium significantly increased the osmotic potential of rice seedlings under stress (Sultana et al., 2001). Li et al. (2003) stated that osmotic potential of liquorice cells was increased by application of calcium chloride.

Leaf free proline ( $\left.\mathrm{mg} \mathrm{g}^{-\mathbf{1}}\right)$ : Proline contents are used to access the plant tolerance to different environmental stresses. Proline contents of pepper as affected by different treatments are shown in Table 1 . At $100 \%$ of field capacity maximum proline contents $\left(1.87 \mathrm{mg} \mathrm{g}^{-1}\right)$ on fresh weight basis were recorded in $\mathrm{CaCl}_{2}$ at $10 \mathrm{mM}$ concentration while they were minimum for control, i.e., $0.31 \mathrm{mg} \mathrm{g}^{-1}$. Proline contents increased (0.47-1.34 $\left.\mathrm{mg} \mathrm{g}^{-1}\right)$ with the increase in concentration of $\mathrm{KCl}$ from 5-15 mM, respectively. Proline accumulation is an important plant capability to alleviate the adverse effects of drought. Proline contents are used to access the plant tolerance to different environmental stresses. Proline accumulation was increased as a result of drought but 
Sci. Technol. Dev., 35 (2): 75-81, 2016

Table 2: No. of flowers, fruit weight, root length, shoot dry weight and Root dry weight at 100 and $50 \%$ of field capacity under different treatments of calcium chloride and potassium chloride

\begin{tabular}{|c|c|c|c|c|c|c|c|c|c|c|}
\hline \multirow[b]{2}{*}{ Treatments } & \multicolumn{2}{|c|}{ No. of flowers } & \multicolumn{2}{|c|}{ Fruit weight (kg) } & \multicolumn{2}{|c|}{ Root length (cm) } & \multicolumn{2}{|c|}{ Shoot dry weight (g) } & \multicolumn{2}{|c|}{ Root dry weight (g) } \\
\hline & $\mathrm{F}_{0}$ & $\mathrm{~F}_{1}$ & $\mathrm{~F}_{0}$ & $\mathrm{~F}_{1}$ & $\mathrm{~F}_{0}$ & $\mathrm{~F}_{1}$ & $\mathrm{~F}_{0}$ & $\mathrm{~F}_{1}$ & $\mathrm{~F}_{0}$ & $\mathrm{~F}_{1}$ \\
\hline $\mathrm{T}_{0}$ & $33.00^{c}$ & $15.89^{f}$ & $3.88^{\mathrm{e}}$ & $0.89^{\mathrm{i}}$ & $41.89^{\mathrm{d}}$ & $23.89^{g}$ & $66.41^{\mathrm{d}}$ & $34.14^{\mathrm{i}}$ & $14.69^{d}$ & $7.72^{\mathrm{h}}$ \\
\hline $\mathrm{T}_{1}$ & $33.45^{c}$ & $16.22^{\mathrm{f}}$ & $4.15^{\mathrm{d}}$ & $1.13^{\mathrm{h}}$ & $43.67^{\mathrm{cd}}$ & $30.00^{\mathrm{f}}$ & $69.78^{\mathrm{cd}}$ & $38.08^{\text {gh }}$ & $15.21^{\mathrm{cd}}$ & $8.33^{\mathrm{g}}$ \\
\hline $\mathrm{T}_{2}$ & $49.55^{\mathrm{a}}$ & $19.22^{\mathrm{e}}$ & $5.49^{\mathrm{a}}$ & $1.30^{\mathrm{h}}$ & $55.67^{\mathrm{a}}$ & $31.56^{\mathrm{ef}}$ & $77.07^{\mathrm{a}}$ & $39.18^{\mathrm{fg}}$ & $16.93^{\mathrm{a}}$ & $8.28^{\text {gh }}$ \\
\hline $\mathrm{T}_{3}$ & $34.78^{c}$ & $27.45^{\mathrm{d}}$ & $4.15^{\mathrm{cd}}$ & $1.89^{f}$ & $42.78^{\mathrm{d}}$ & $46.67^{\mathrm{bc}}$ & $72.93^{\mathrm{bc}}$ & $48.93^{e}$ & $16.14^{\mathrm{b}}$ & $10.75^{\mathrm{e}}$ \\
\hline $\mathrm{T}_{4}$ & $33.45^{\mathrm{c}}$ & $17.11 \mathrm{e}^{\mathrm{f}}$ & $4.19^{\text {cd }}$ & $1.11^{\mathrm{hi}}$ & $44.33^{\mathrm{cd}}$ & $31.45^{\mathrm{ef}}$ & $70.02^{c}$ & $34.94^{\mathrm{hi}}$ & $15.33^{c}$ & $8.39^{g}$ \\
\hline $\mathrm{T}_{5}$ & $34.33^{c}$ & $19.00^{\mathrm{e}}$ & $4.38^{c}$ & $1.24^{\mathrm{h}}$ & $44.55^{\mathrm{cd}}$ & $32.78^{\text {ef }}$ & $72.09^{\mathrm{bc}}$ & $42.43^{f}$ & $16.02^{\mathrm{b}}$ & $9.22^{f}$ \\
\hline $\mathrm{T}_{6}$ & $44.89^{\mathrm{b}}$ & $25.56^{d}$ & $4.99^{\mathrm{b}}$ & $1.57^{\mathrm{g}}$ & $48.67^{b}$ & $33.45^{\mathrm{e}}$ & $74.16^{\mathrm{ab}}$ & $37.82^{\mathrm{gh}}$ & $17.10^{\mathrm{a}}$ & $8.24^{\text {gh }}$ \\
\hline
\end{tabular}

increase in proline contents of bell pepper leaves by foliar application of calcium chloride and potassium chloride was greater than control (Table 1). Maximum proline contents $\left(4.29 \mathrm{mg} \mathrm{g}^{-1}\right)$ on fresh weight basis were recorded in $\mathrm{CaCl}_{2}$ at $15 \mathrm{mM}$ concentration while they were minimum for control, i.e., $1.32 \mathrm{mg} \mathrm{g}^{-1}$. Proline contents increased (1.64-4.29 $\mathrm{mg} \mathrm{g}^{-1}$ ) with increase in concentration of $\mathrm{CaCl}_{2}$ from 5-15 mM, respectively.

Calcium works as a secondary messenger which helps in various plant functions from nutrient uptake to changes in cell status to help the plant react to the impact of environmental stresses. Every major step of protein synthesis requires potassium. The increase in proline contents may be due to this effect of calcium chloride and potassium chloride. Adequate $\mathrm{K}$ is essential to read the genetic code in plant cells for the production of proteins and enzymes that regulate all growth processes. Our results agreed with Pothalkar (2007) who described that proline contents in pigeon pea were increased by application of $\mathrm{CaCl}_{2}$ (2\%). Thalooth et al. (2006), stated that proline contents of mungbean plants were increased by application of external potassium as compared to control plants under drought.

Number of flowers per plant: Observations relating to number of flowers are shown in Table 2. It is clear from the observations that there was a significant increase with different concentrations regarding number of flowers at $100 \%$ of field capacity. Maximum average number of flowers per plant was produced by $\mathrm{CaCl}_{2}$ at $10 \mathrm{mM}$ concentration, i.e., 49.55, while they were minimum in control, i.e., 33. Potassium chloride showed an increasing trend in number of flowers with increase in concentration. Water deficit reduced the number of flowers per plant. Maximum average number of flowers per plant was produced by $\mathrm{CaCl}_{2}$ at $15 \mathrm{mM}$ concentration, i.e., 27.45, while they were minimum in control, i.e., 15.89 (Table 2). Potassium chloride and calcium chloride showed an increasing trend in number of flowers with the increase in concentration.

The quality of the fruit produced and the structural integrity of stems that hold flowers and fruit is strongly coupled to calcium availability. Number of flowers per plant was increased significantly in zinnia plant when they were sprayed with $\mathrm{CaCl}_{2} 2000 \mathrm{mg} \mathrm{L}^{-1}$ (Garib, 2008). Number of flowers in German chamomile was increased with the increase in potassium level from $0-50 \mathrm{~kg} \mathrm{~h}^{-1}$ (Reza et al., 2012).

Fruit weight per plant (kg): Fruit weight per plant was significantly increased by different concentrations of $\mathrm{CaCl}_{2}$ and $\mathrm{KCl}$ as compared to control (Table 2). Analysis of variance showed that all treatments produced more fruit than control when there was no water stress. Calcium chloride at rate of $10 \mathrm{mM}$ gave maximum fruit weight per plant $(5.49 \mathrm{~kg})$ while it was minimum in control, i.e., $3.88 \mathrm{~kg} \mathrm{plant}^{-1}$. Fruit weight increased with increase in concentration of $\mathrm{KCl}$. There was a decrease in fruit weight per plant under drought. Observations regarding fruit weight per plant showed that there was a significant increase in fruit weight by different treatments of calcium chloride and potassium chloride. Calcium chloride at rate of $15 \mathrm{mM}$ gave maximum fruit weight per plant $(1.89 \mathrm{~kg})$ while it was minimum in control, i.e., $0.89 \mathrm{~kg} \mathrm{plant}^{-1}$. Both chemicals showed an increasing trend for fruit weight as we increased their concentrations.

Fruit yield is our major goal in the experiment. Fruit yield was increased by foliar application of $\mathrm{CaCl}_{2}$ and $\mathrm{KCl}$ as they increased number of flowers and fruits. Also they have a significant role in antioxidant activities. Foliar application of potassium significantly increased total yield of sweet pepper (El-Bassiony et al., 2010). Fruit yield of tomato plants was increased by application of calcium as it increased the uptake of nitrogen by the fruits. The increase in fruit yield may also be due to the increase in root primordial that results in greater absorption of nutrients (Siddiq et al., 2009). Thalooth et al. (2006), stated that yield and yield components of mungbean were increased by application of foliar applied potassium under water deficit conditions.

Root length (cm): Average root length was measured by uprooting the plants from each treatment. Root length is a good indicator of plant to absorb more water and 
nutrients from soil and produces more biomass. Root length of pepper plants as affected by different concentrations of $\mathrm{CaCl}_{2}$ and $\mathrm{KCl}$ is shown in Table 2, which showed that there was an increase in root length by different concentrations of foliar applied calcium chloride and potassium chloride. Maximum root length was obtained in $\mathrm{CaCl}_{2}$ at $10 \mathrm{mM}$ concentration, i.e., $55.67 \mathrm{~cm}$, while it was minimum in control, i.e., $41.89 \mathrm{~cm}$. Potassium chloride showed an increasing trend in root length with the increase in its concentration. As a result of drought, plants convert their energies to produce more and lengthy roots so that they can absorb more water and nutrients. Both chemicals help the plants to increase their root lengths. Observations of root lengths as affected by different concentrations of $\mathrm{CaCl}_{2}$ and $\mathrm{KCl}$ showed that maximum root length was obtained in $\mathrm{CaCl}_{2}$ at $15 \mathrm{mM}$ concentration, i.e., $46.67 \mathrm{~cm}$, while it was minimum in control, i.e., $23.89 \mathrm{~cm}$. Potassium chloride and calcium chloride showed an increasing trend in root length with increase in their concentrations.

Calcium and potassium improves sugar translocation, cell division and elongation, growth of meristematic tissues so the increase in root length may be due to these effects. Calcium chloride significantly increased the root length of zinnia plants (Garib, 2008). Our result also agreed with Kiran (2006), who noticed a significant increase of root length in brinjal plants by the application of potassium fertilizer.

Shoot and root dry weight (g): Shoot and root weights are important parameters to measure the efficiency of the crop. There was a significant increase in shoot and root dry weight by different concentrations of $\mathrm{CaCl}_{2}$ and $\mathrm{KCl}$. Analysis of variance showed that at $100 \%$ of field capacity maximum shoot dry weight was produced by $\mathrm{CaCl}_{2}$ at $10 \mathrm{mM}$ concentration, i.e., $77.07 \mathrm{~g}$, while it was minimum for control, i.e., $66.41 \mathrm{~g}$ (Table 2). All the treatments were significantly higher than control. Similarly, maximum root dry weight was produced by $\mathrm{CaCl}_{2}$ at $10 \mathrm{mM}$ concentrations i.e., $17.09 \mathrm{~g}$ while it was minimum for control, i.e., 14.69 g (Table 2). Root and shoot dry weights showed an increasing trend with the increase in the concentration of $\mathrm{KCl}$. All the concentrations were significantly higher than control regarding root dry weight.

Shoot and root weights are important parameters to measure the efficiency of crop. As drought reduced the efficiency of different functions of plants so reduction in shoot and root dry biomass was also occurred. Both chemicals helped the plants to produce more shoot and root biomass. A significant increase in shoot and root dry weights was observed by different concentrations of $\mathrm{CaCl}_{2}$ and $\mathrm{KCl}$. Statistical of analysis of variance showed that maximum shoot dry weight was produced by $\mathrm{CaCl}_{2}$ at $15 \mathrm{mM}$ concentration, i.e., $48.93 \mathrm{~g}$, while it was minimum for control, i.e., $34.14 \mathrm{~g}$ (Table 2). Similarly maximum root dry weight was produced by $\mathrm{CaCl}_{2}$ at $15 \mathrm{mM}$ concentration, i.e., $10.75 \mathrm{~g}$, while it was minimum for control, i.e., $7.72 \mathrm{~g}$ (Table 2).

The $\mathrm{CaCl}_{2}$ was sprayed on zinnia plants at the rate of $1 \mathrm{~g} \mathrm{~L}^{-1}$; it significantly increased the shoot and root dry weights of zinnia plant (Garib, 2008). Our results also agreed with Siddiq et al. (2009), who described that shoot and root dry weights of tomato plants were significantly increased by the application of calcium and potassium fertilizers. Mungbean plants were subjected to drought at different growth stages. Foliar application of $\mathrm{K}^{+}$ significantly increased all growth parameters (Thalooth et al., 2006).

\section{CONCLUSION}

The study was conducted to cope with water shortage problem in the production of vegetables emphasizing bell pepper. It can be concluded from the present study that both calcium chloride and potassium chloride helped the pepper plants to improve different chemical and yield parameters at normal and water deficit irrigation. Calcium chloride at $10 \mathrm{mM}$ showed better results than other treatments under normal irrigation while calcium chloride at $15 \mathrm{mM}$ showed better results under drought conditions. With the application of different nutrients, we can manage the stress resulting increase in production, however further studies are needed in subject.

\section{REFERENCES}

Bates, L.S., R.P. Waldren and I.D. Teare, 1973. Rapid determination of free proline for water-stress studies. Plant Soil, 39: 205-207.

Bednarz, C.W., D.M. Oosterhuis and R.D. Evans, 1998. Leaf photosynthesis and carbon isotope discrimination of cotton in response to potassium deficiency. Environ. Exp. Bot., 39: 131-139.

Braam, J., 1992. Regulated expression of the calmodulin-related TCH genes in cultured Arabidopsis cells: Induction by calcium and heat shock. Proc. Natl. Acad. Sci. USA., 89: 3213-3216.

Brauer, M., D. Sanders and M. Stitt, 1990. Regulation of photosynthetic sucrose synthesis: A role for calcium? Planta, 182: 236-243. 
Bush, D.S., 1995. Calcium regulation in plant cells and its role in signaling. Annu. Rev. Plant Physiol. Plant Mol. Biol., 46: 95-122.

Cabanero, F.J. and M. Carvajal, 2007. Different cation stresses affect specifically osmotic root hydraulic conductance, involving aquaporins, ATPase and xylem loading of ions in Capsicum annuum, L. plants. J. Plant Physiol., 164: 1300-1310.

Clarkson, D.T. and J.B. Hanson, 1980. The mineral nutrition of higher plants. Ann. Rev. Plant Physiol., 31: 239-298.

Cosgrove, D.J. and R. Hedrich, 1991. Stretch-activated chloride, potassium and calcium channels coexisting in plasma membranes of guard cells of Vicia faba L. Planta, 186: 143-153.

Debaeke, P. and A. Aboudrare, 2004. Adaptation of crop management to water-limited environments. Eur. J. Agron., 21: 433-446.

Eisenman, G., 1961. On the Elementary Atomic Origin of Equilibrium Ionic Specificity. In: Symposium on Membrane Transport and Metabolism, Kotyk, A. (Ed.). Springer, New York, pp: 163-179.

El-Bassiony, A.M., Z.F. Fawzy, E.H. Abd El-Samad and G.S. Riad, 2010. Growth, yield and fruit quality of sweet pepper plants (Capsicum annuum L.) as affected by potassium fertilization. J. Am. Sci., 6: 123-128.

Elumalai, R.P., P. Nagpal and J.W. Reed, 2002. A mutation in the arabidopsis KT2/KUP2 potassium transporter gene affects shoot cell expansion. Plant Cell, 14: 119-131.

Epstein, E., 1972. Mineral Nutrition of Plants: Principles and Perspectives. Whiley, New York, USA.

FAO., 2013. FAOSTAT database. http://faostat3.fao.org/ download/Q/QC/E.

Ferrara, A., S. Lovelli, T. Di Tommaso and M. Perniola, 2011. Flowering, growth and fruit setting in greenhouse bell pepper under water stress. J. Agron., 10: 12-19.

Flowers, T.J. and A. Lauchli, 1983. Sodium Versus Potassium: Substitution and Compartmentation. In: Encyclopedia of Plant Physiology 158. Inorganic Plant Nutrition, Lauchli, A. and A. Pirson (Eds.). Springer, Berlin, pp: 651-681.

Garib, S.B., 2008. Effect of cycocel spray and calcium chloride on the growth and flowering of Zinnia elegnas Taeq. J. Duhok Univ., 12: 39-43.

Gilroy, S., N.D. Read and A.J. Trewavas, 1990. Elevation of cytoplasmic calcium by caged calcium or caged inositol trisphosphate initiates stomatal closure. Nature, 346: 769-771.

Gonzalez-Dugo, V., F. Orgaz and E. Fereres, 2007. Responses of pepper to deficit irrigation for paprika production. Scientia Horticulturae, 114: 77-82.
Hirayama, M., Y. Wada and H. Nemoto, 2006. Estimation of drought tolerance based on leaf temperature in upland rice breeding. Breeding Sci., 56: 47-54.

Hsiao, T.C. and A. Lauchli, 1986. A Role of Potassium in Plant-Water Relations. In: Advances in Plant Nutrition, Tinker, P.B., A. Lauchli and E. Tinker (Eds.). Vol. 2, Praeger Scientific, New York, USA., pp: 281-311.

Hsiao, T.C., 1973. Plant responses to water stress. Annu. Rev. Plant Physiol., 24: 519-570.

Hsiao, T.C., 1993. Growth and productivity of crops in relation to water status. Acta Horticulturae, 335: 137-148.

Kiran, J., 2006. Effect of fertilizer, biofertilizer and micronutrients on seed yield and quality of brinjal (Solanum melongena L.). M.Sc. Thesis, University of Agricultural Sciences, Dharwad.

Kochian, L.V. and W.J. Lucas, 1988. Potassium Transport in Roots. In: Advances in Botanical Research, Callow, J.A. (Ed.). Academic Press Ltd., London, UK., pp: 93-178.

Lauchli, A., 1984. Mechanisms of Nutrient uxes at Membranes of the Root Surface and their Regulation in the Whole Plant. In: Roots, Nutrient and Water Influx and Plant Growth, Barber, S.A. and D.R. Bouldin (Eds.). 3rd Edn., Soil Science Society of America, Madison, USA., ISBN: 9780891180821 , pp: 1-25.

Li, M., G.X. Wang and J.S. Lin, 2003. Application of external calcium in improving the PEG-induced water stress tolerance in liquorice cells. Bot. Bull. Acad. Sinica, 44: 275-284.

Lindhauer, M.G., 1987. Potassium and phosphorus: Solute concentrations in well watered and water stressed sunflower plants differing in K nutrition. J. Plant Nutr., 10: 1965-1973.

Ling, F. and M. Silberbush, 2002. Response of maize to foliar vs. soil application of nitrogen-phosphoruspotassium fertilizers. J. Plant Nutr., 25: 2333-2342.

Lino, M., M. Endo and M. Wada, 1989. The occurrence of a $\mathrm{Ca}^{2+}$-dependent period in the red light-induced late G1 Phase of germinating Adiantum spores. Plant Physiol., 91: 610-616.

Maathuis, F.J.M. and D. Sanders, 1996. Mechanisms of potassium absorption by higher plant roots. Physiol. Plant., 96: 158-168.

Martens, J.W. and D.C. Arny, 1967. Effects of potassium and chloride ion on root necrosis, stalk rot and pith condition in corn (Zea mays L.). Agron. J., 59: 499-502.

Maynard, D.N. and G.J. Hochmuth, 1997. Knott's Handbook for Vegetable Growers. 4th Edn., John Willey and Sons Inc., New York, USA., ISBN-13: 9780471131519, Pages: 582. 
Mengel, K. and E.A. Kirkby, 1987. Principles of Plant Nutrition. 4th Edn., International Potash Institute, Bern, Switzerland, pp: 434-440.

Mengel, K. and E.A. Kirkby, 2001. Principles of Plant Nutrition. 5th Edn., Kluwer Academic Publishers, Dordrecht, Netherland, ISBN-13: 9781402000089, Pages: 849.

Palaniappan, S.P., A. Jeyabal and S. Chelliah, 1999. Response of tomato and chilli to foliar application of speciality fertilizers. Vegetable Sci., 26: 198-200.

Pothalkar, S.M., 2007. Physiological investigations on drought tolerance in pigeonpea (Cajanus cajan L.). Ph.D. Thesis, University of Agricultural Sciences, Dharwad.

Reza, M.N., M.S. Mohammad, Z. Houseyn and B. Bahari, 2012. Effects of different levels of nitrogen, phosphorus and potassium fertilizers on some agromorphological and biochemical traits of German chamomile (Matricaria chamomilla L.). J. Med. Plant Res., 6: 227-283.

Sanders, D., C. Brownlee and J.F. Harper, 1999. Communicating with calcium. Plant Cell, 11: 691-706.

Schroeder, J.I., J.M. Ward and W. Gassmann, 1994. Perspectives on the physiology and structure of inward-rectifying $\mathrm{K}^{+}$channels in higher plants: Biophysical implications for K uptake. Annu. Rev. Biophys. Biomol. Struct., 23: 441-471.

Siddiq, S., M. Yaseen, S.A.R. Mehdi, A. Khalid and S.U.R. Kashif, 2009. Growth and yield response of tomato (Lycopersicon esculentum Mill.) to soil applied calcium carbide and L-methionine. Pak. J. Bot., 41: 2455-2464.

Siddique, M.R.B., A. Hamid and M.S. Islam, 2000. Drought stress effects on water relations of wheat. Bot. Bull. Acad. Sin., 41: 35-39.
Steel, R.G.D., J.H. Torrie and M.A. Boston, 1997. Principles and Procedures of Statistics: A Biometrical Approach. 3rd Edn., McGraw Hill Book Company Inc., New York, USA., ISBN-13: 9780070610286, Pages: 666.

Sultana, N., T. Ikeda and M.A. Kashem, 2001. Effect of foliar spray of nutrient solutions on photosynthesis, dry matter accumulation and yield in seawater-stressed rice. Environ. Exp. Bot., 46: 129-140.

Taiz, L. and E. Zeiger, 2002. Plant Physiology. 3rd Edn., Sinauer Associates Inc., Sunderland, MA., USA., ISBN-13: 9780878938230, Pages: 690.

Tester, M. and R. Zorec, 1992. Cytoplasmic calcium stimulates exocytosis in a plant secretory cell. Biophys. J., 63: 864-867.

Thalooth, A.T., M.M. Tawfik and M.H. Mohamed, 2006. A comparative study on the effect of foliar application of zinc, potassium and magnesium on growth, yield and some chemical constituents of mungbean plants grown under water stress conditions. World J. Agric. Sci., 2: 37-46.

Ward, J.M. and J.I. Schroeder, 1994. Calcium-activated $\mathrm{K}^{+}$channels and calcium-induced calcium release by slow vacuolar ion channels in guard cell vacuoles implicated in the control of stomatal closure. Plant Cell, 6: 669-683.

Yin, X. and T.J. Vyn, 2002. Soybean responses to potassium placement and tillage alternatives following no-till. Agron. J., 94: 1367-1374.

Zhang, Z.S., R.Q. Li and J.B. Wang, 2001. Effects of $\mathrm{Ca}^{2+}$ pretreatment on plasmalemma permeability, GSH and ASA contents and calcium distribution in pepper mesophyll cells under heat stress. Chin. J. Plant Ecol., 25: 230-234. 